\title{
13
}

\section{RADICAL-RIGHT POLITICAL ACTIVISM ON THE WEB AND THE CHALLENGE FOR EUROPEAN DEMOCRACY}

\section{A perspective from Eastern and Central Europe}

\author{
Manuela Caiani and Pál Susánszky
}

\section{Introduction}

The radical right ${ }^{1}$ is on the rise both in the real world and online, not only in Western European democracies (Caiani, Della Porta, and Wagemann 2012; Hutter 2014) but also in Central and Eastern Europe (Buštíková 2018; Greskovits 2020). Overall, compared with the 1970s ('radical right first wave') and early 1990s ('second wave'), the turn of the century was marked by an increasing activity of radicalright organisations in institutional politics ('third wave') (Mudde 2017), especially after the 2008 economic crisis (Kriesi and Pappas 2015). Yet scholars started to talk about the beginning of a fourth wave (of normalisation) of these political forces. The radical right is mainstreamed (Mudde 2019). Also, new forms of radical-right social movements and protest mobilisations emerged (e.g. Pegida in Germany) (Bernhard and Kriesi 2019; Hutter 2014), which often work as 'incubators' of new political ideas and radical-right voters (Minkenberg 2013). In parallel, the success of radical right-wing online mobilisation has become quite obvious (Ekman 2018; Klein and Muis 2019; Kluknavská and Hruška 2019). As the Europol IOCTA 2019 report stressed: "the interplay of online [right-wing extremist] communities who share the same Internet slang and memes contributed to the widespread dissemination of the content and its digital endurance" (49). In fact, the issues around which radical-right groups mobilise their followers - such as Islamisation, globalisation, immigration, etc. - are highly debated on their websites (for an overview on Western Europe, see Caiani and Parenti 2013).

If the "mobilization of the losers" (Kriesi 2014) or "the new cleavage" in search of political entrepreneurs theses (Kriesi 2018) are often quoted to account for this recent radical-right revitalisation in European democracies, the role played by the Internet as a new tool of political mobilisation and communication is also gaining serious consideration among scholars (e.g. Bartlett, Birdwell, and Littler 2011), as the book within which this chapter is located testifies. In particular the 
radical-right use of the web is linked to hate speech and fake news (Klein 2019; Monti 2018). A recent study on the visual propaganda of the British National Party on Facebook, for example, (Klein 2019) stressed that half of the shared pictures (50\%) were "manipulative" and "framed with selective statistics", especially against immigrants and Muslim people, encouraging online activism against them among the followers of the party.

The topic (i.e. radical-right political activism on the web) appears particularly crucial in Eastern and Central Europe since, as underlined, post-communist countries face challenges regarding their membership in the European Union. Moreover, parallel with the rise of nationalist radical-right politics, the quality of democracy has decayed, (Minkenberg 2017: 1-9).

In this chapter we address this topic by focussing on four Central Eastern European countries (the Czech Republic, Hungary, Poland, and Slovakia) and analysing, through a systematic formalised content analysis (for a similar method and tools see Caiani and Parenti 2013) on all radical right websites identified, the degree and forms of the use of the web by these political actors (from political parties to cultural radical websites, to neo-Nazi groups). A particular attention will be devoted to the textual and visual forms of radical-right online propaganda, as well as differences and similarities across various type of groups and countries. A comparison between Eastern and Western radical-right organisations on the use of the web and propaganda will be presented.

Indeed, to date, empirical research on the radical right and their political mobilisation, identity promotion and propaganda online is quite fragmented and selective, focussing still mainly on political parties (although with some important exceptions, e.g. Castelli Gattinara and Pirro 2019) and almost exclusively on Western countries (for some exceptions, see: Fofiu, 2015; Andreescu 2015; Karl 2017). Moreover, although the current resurgence of the radical right in Central Eastern Europe (CEE) has received much scholarly attention in recent years, most of these studies focus on offline radical-right activities (e.g. Minkenberg 2015; Mudde 2017; Pytlas 2015; Císař and Štětka 2016; Císař 2017) or online radicalright activism concerning single case studies (e.g. the Jobbik movement in Hungary). Comparative researches on radical-right online political activities in these countries are still rare.

Who are the radical right organisations active online in CEE? How do they address and attempt to reach out their supporters through the web? What kind of content is spread by radical-right organisations online, and which goals do they pursue? This study, with the limit of focussing on solely four Central Eastem European countries (the Czech Republic, Hungary, Poland, and Slovakia), tries to shed light systematically on these questions and offer an empirical contribution to them.

The chapter is organised as follows. In the first section we summarise the academic state of the art concerning the role of the Internet in radical-right mobilisation. After having illustrated our method and the sources of this study (section two), section three shows the comparative (cross-country and cross-organisational 
type) empirical analysis of radical-right political activism online, and section four concludes by critically discussing these findings in light of the challenge to European democracies (in particular as far as CEE is concerned).

\section{The role of the Internet in radical-right organisations}

Social movement scholars have argued that the Internet offers several advantages for the mobilisation of civil society collective actors, including low costs, fast and efficient communications for connecting isolated individuals and groups, along with tools for coordination and socialisation which are especially helpful to overcome problems of leadership (see, among others, Bennett and Segerberg 2013; Bennett, Breunig, and Givens 2008; Van Laer and Van Aelst 2010). It is said to allow new forms of political participation (Van Laer and Van Aelst 2010) as well as to organise collective actions more easily (Dolata and Schrape 2016). This is even more true for radical actors for whom the web provides a virtual arena in which they can have their views and lower the risk of being banned or persecuted (Caiani, Della Porta, and Wagemann 2012; Klein and Muis 2019). Online platforms help such movements to disseminate messages, organise and mobilise for protests, make symbolic actions, and "provide an opportunity to express oneself in "online communities" (Krämer 2017: 12). In fact, it has been stressed that the Internet may reduce the cost of radical-right mobilisations, also transnational ones, such as those organised by Pegida (Caiani and Kroel 2014; Enikolopov, Makarin, and Petrova 2016; Berntzen and Weisskircher 2016) and it can allow these actors to build an active and potent self-image with little effort (Arzheimer 2015; Berntzen and Weisskircher 2016). Finally, studies on social movements argue that the Internet can help in generating collective identities by facilitating the exchange of resources and information, as well as creating solidarity and shared objectives (Della Porta and Mosca 2006) and this is a crucial function for those radical-right political actors, who often feel marginalised from society. As it has been illustrated by recent research, "social media" works "as a second home" for radicals, and a form of "virtual shelter" for these groups (De Koster and Houtman 2008).

All these developments may open new opportunities for the mobilisation of radical-right organisations (as well as challenges for European democracies), which, in the shadow of the great recession, can capitalise on the discontent of the losers of globalisation (Kriesi et al. 2008) via the web (Caiani 2019). In this study, among the various functions the Internet can play for radical-right actors (i.e. mobilisation, identity formation, propaganda, communication, and recruitment, etc; see Caiani and Parenti 2013 for an overview), we will investigate the actual degree and forms of radical-right online activism in our selected countries.

Radical-right organisations are, in general, identified according to a common definition that includes, as core ideological elements: nationalism - i.e., the strong preference for a homogeneous nation (Minkenberg 2015), law and order, racism, conservative values, and anti-system or anti-establishment critiques (Mudde 2007). In this study, we have adopted this definition too, however, it should be 
considered that these political actors in the CEE have some specificities: a main focus on 'internal enemies', such as Roma groups or Jews instead of 'immigrants' as in Western Europe (Pirro 2015b); the communist legacy (Pytlas 2013), which made the radical right a more acceptable political actor in the public sphere; as well as a peculiar form of national identity ${ }^{2}$ (Minkenberg 2017), made of strong nationalism (since most of CEE countries gained their independence relatively recently) and xenophobic sentiments more against aforementioned internal enemies rather than external immigrants. In this study the identification and classification of various radical-right organisations has been based on the self-definition of the groups and the content of the message transmitted through their websites.

\section{Methods and data}

In order to identify all radical right organisations with an online presence in our four countries we used a snowball technique, starting from the most important and well-known groups in each country and following explicit web links (e.g. 'our partners', 'our friends') to other radical right groups. ${ }^{3}$ This allowed us to identify a total of 188 organisations, around $40-50$ in each country. We then conducted a web content analysis on these radical-right organisational websites, using a formalised codebook consisting of more than 70 variables (open and closed questions) trying to capture several different functions of the political use of the web by these groups such as: propaganda, mobilisation, internationalisation, communication, and the creation of a collective identity/ideology. For each of these broader aspects we elaborated lower level indicators. ${ }^{4}$

Our research design includes two comparative dimensions: cross-national and cross-right-wing organisational type. As for the case selection, our four Central Eastern European countries have been chosen because, despite some common historical legacies (e.g. the communist past before 1989, the democratic transition in the early 1990s, and the accession to the European Union in 2004), they provide sufficient variation on the factor we consider relevant for understanding radicalright mobilisation (also online). They are: in terms of political opportunities for radical-right mobilisation, a different role of the so called 'allies in power' (i.e. different strength and duration of the radical-right electoral success) (Krekó, Juhász and Molnár 2011; for details on different countries, see Caiani and Císař 2018); different organisational milieu and associational life of the radical right, which offers a different 'market of consumers' for their online activism (Caiani and Parenti 2013); laws against the Nazi-fascist past; as well as variation in radical-right ideology along the history and activity of the radical-right actors (Minkenberg 2017) - which can influence the forms and content of their use of the web to do politics.

Moreover, this study focusses on both political parties and non-party organisations, including violent groups. They are:

(1) radical-right political parties ${ }^{5}$ such as the Slovak Nationalist Party (Slovenská Národná Strana) in Slovakia, the Jobbik in Hungary; the Freedom and Direct 
Democracy (Svoboda a Prímá Demokracie) in the Czech Republic, the National Movement (Ruch Narodowy) in Poland;

(2) radical-right movements ${ }^{6}$ such as, for instance, the Sixty-four Counties Youth Movement (Hatvannégy vármegye ifjúsági mozgalom) in Hungary, the Endecja Club movement of young intellectuals in Poland;

(3) neo-Nazi groups ${ }^{7}$ such as paramilitary groups - e.g. Troop of Social Bandits (Betyársereg) in Hungary, or the Aryan Rebel white supremacy group in the Czech Republic);

(4) revisionist/negationist and nostalgic ${ }^{8}$ groups such as, for instance, the Trianon Association in Hungary or the National Institute for Education (Národne Vzdělávací Institute) in the Czech Republic;

(5) cultural and commercial organisations ${ }^{9}$ such as for instance the Brotherhood e-shop in Slovakia or the Hungarian warrior clothes shop (Magyar Harcos);

(6) subcultural youth organisations, skinheads, music and sports groups ${ }^{10}-$ e.g. the Sztorm 68 Polish skinhead band, Czech Hooligans group, Hungarian football Ultras;

(7) right-wing nationalists, present especially in Poland, ${ }^{11}$ such as the National Rzeszow- National Leczna.

As we will show below, in the CEE countries under examination the radical-right area is not a monolithic actor (Minkenberg 2017), and this is also the case online: they use a broad repertoire of (visual and textual) online propaganda with different intensity and for different purposes.

\section{Visual and textual propaganda via the web}

As we can see from Figure 13.1, our analysis focusses on several broad aspects that we consider relevant to Internet used by right-wing groups, such as communication, ideology, internationalisation, mobilisation, with a particular view to propaganda. With regard to propaganda, the lower level indicators were variables capturing the presence of content concerning radical-right online propaganda towards both insiders and outsiders, such as: slogans, hate symbols, logos, narratives about operations of the groups, the names of the leader, news section, internal search engine, documentation material, and hit counter.

The dissemination of propaganda accounts for, in general, the most extensive use of the web by these organisations, across countries and types of groups (data not showed). In particular, our data suggests that the Polish radical-right groups are very active on their websites and also in their communication (e.g. they are reachable to the public, indicating on their websites their offices, information about the meeting point of the group, phone and mail, etc); Czech radical-right organisations have relatively extended international contacts with actors who operate in foreign countries, with a clear goal to use the web to build transnational contacts with similar organisations; Slovak groups show an average activity in all dimensions; and, finally, the Hungarian radical right seems to be in general less active 


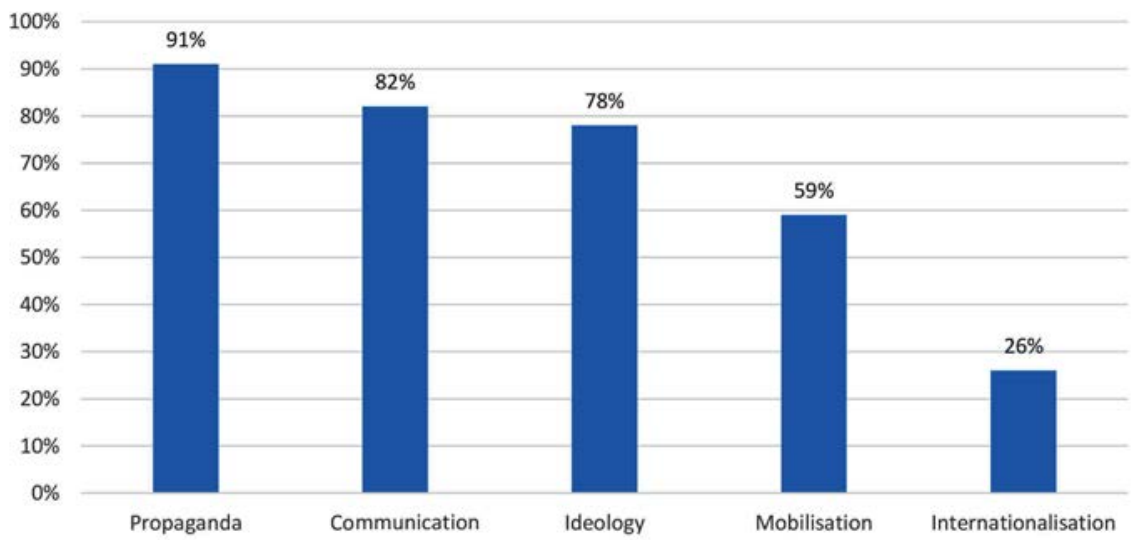

FIGURE 13.1 The political functions of radical-right websites in Central Eastern Europe $\mathrm{N}=188$; mean values are showed.

online, something suggesting that the inverse relation hypothesis is at least partly confirmed (Hutter 2014). According to the inverse relation hypothesis between institutional and protest radical-right politics, it is not surprising to find a moderate level of online activism in the country (Hungary) where the radical right possess a super majority in government and in parliament since several mandates. In regards to propaganda, as we can see from Table 13.1, we have distinguished two forms of online propaganda: (1) textual and (2) visual. Textual forms of propaganda includes textual elements like: slogans, bibliography, conference materials, or articles. While pictures, hate symbols, maps, banners or video footage are coded as elements of the visual radical-right propaganda. Indeed, if one important function of these materials is rank and file mobilisation, recent studies have particularly emphasised the important role played by political pictures in online mobilisation (Kharroub and Bas 2016; Powell et al. 2015). According to a recent study by Casas and Webb Williams (2017), visual materials (e.g. pictures, symbols, banners) are particularly

TABLE 13.1 Textual and visual online radical-right propaganda, by country

\begin{tabular}{lcll}
\hline Countries & Propaganda $(\%)$ & Textual propaganda $(\%)$ & Vistal propaganda $(\%)$ \\
\hline HU & 76.4 & 61.8 & 67.3 \\
PL & 92.9 & 81.0 & 73.8 \\
CZ & 98.0 & 94.1 & 92.2 \\
SK & 100.0 & 95.0 & 87.5 \\
Total & 91.0 & 81.9 & 79.8 \\
\hline
\end{tabular}

$\mathrm{N}=188$; mean values are showed. Abbreviations: HU (Hungary); PL (Poland); SK (Slovakia); CZ (Czech Republic) 
effective for political mobilisation, since they 'work' through mechanisms that trigger emotions (e.g. enthusiasm, fear) addressing the passionate side of politics, and spark self-efficacy (Casas and Webb Williams 2017).

Our data shows that in the CEE countries, online propaganda (both visual and textual, $82 \%$ and $80 \%$ respectively) is widely used on the homepages of radicalright organisations and that, beyond the instrumental uses of the Internet (e.g. for mobilisation, recruitment, or fundraising), the majority of CEE right-wing groups are strongly oriented to propaganda (and therefore the use of the Internet for collective identity formation) towards members or sympathisers, ${ }^{12}$ offering a rich repository of documents, photos, and propaganda material explicitly recalling nationalist, xenophobic, fascist, and Nazi iconography and rhetoric.

However, there are significant differences across the four countries. Slovak and Czech right-wing websites are the most active both in textual and visual forms of online propaganda $(100 \%$ and $98 \%$ respectively). On the other hand, we found less propaganda material on the Hungarian and Polish homepages (76\% and 93\% respectively).

Examining national differences in further details, about visual propaganda we can see that one-fifth of the websites $(20.7 \%)$ in the countries analysed contain 'hate symbols' such as swastikas, tristikas, and historical fascist symbols such as the arrow cross (used by the Hungarian Nationalist Movement) or the short gladio sword; ${ }^{13}$ photos of nationalist leaders such as Hitler, Ferenc Szálasi or Andrej Hlinka; images related to the Third Reich; and flags from the local fascist pasts (with local symbols such as the phalanx, arrow crosses etc.). Militarist symbols (guns, marching soldiers, historical armed forces' emblems, etc.) also frequently appear, as do Celtic crosses. ${ }^{14}$

Data shows that hate symbols are most likely to be present on the websites of Polish and Hungarian radical-right organisations (42.9\% and 25.5\%), whereas Slovak and Czech right-wing websites are the least likely to have them $(7.5 \%$ and $7.8 \%$ ). These results can be linked to the context of stricter laws against the Nazi-fascist past in certain countries. ${ }^{15}$ Half of websites contain banners ${ }^{16}$ depicting representative figures, and graphic symbols or seals intended to incite hatred against social and/or political adversaries, such as 'left-leaning clubs' that are targeted by the Polish group Aktyw Pólnocy. Otherwise, banners are most frequent on the Slovak and Czech websites (72.4\%, 80.5\%) and least on Hungarian websites (7.3\%).

As mentioned earlier with regard to propaganda aimed towards outsiders, the main objective is recruitment, and the web is becoming a crucial device for that (Street 2011: 263). Neo-Nazis use the Internet and music primarily to reach out to youth members as, for many young people online, communication has become the most important tool for exchanging news and views on the world, and it is their main source of information. According to our analysis, whose main results are synthesised in Table 13.2, 'multimedia materials' are present in half of right-wing sites $(50 \%)$. 
Turning to the textual materials, we find textual propaganda slightly more frequently on radical-right webpages than pictures and other visual information. The most frequent element of textual propaganda is the 'articles' (66\%), a section in which the group provide papers, articles, or dossiers. Czech and Slovak websites contain more $(86.3 \%$ and $77.5 \%$ respectively), while Hungarian and Polish sites cite less of these materials $(40.0 \%, 64.3 \%)$.

One-third of the radical-right websites analysed contain slogans, 17\% bibliographical sources, and finally only a minority of radical-right organisations (7.4\%) have a section in which they cite conference materials.

Beyond country contexts, however, we noticed also differences in the political use of the web by radical-right organisations according to the 'type' of group at stake. In particular, movements, neo-Nazi and nationalistic organisations use frequent multimedia material (in $23.4 \%, 19.1 \%$, and $19.1 \%$ of cases respectively). Political movements and nostalgic organisations most commonly offer 'bibliographical references' (present in $21.2 \%$ in both instances). On the contrary, commercial groups and political parties seem the least oriented towards using 'bibliography' (in $6.1 \%$ and $3 \%)$.

On the other hand, cultural and commercial organisations are the least, but political movements are the most likely to have 'articles and/or papers and/or dossiers' on their pages.

Some right-wing organisations (often political parties) also provide more advanced multimedia materials. Also very common are videos of demonstrations and captions of direct actions (clashes with the police, confrontations of the police/'ordinary citizens' with refugees, immigrants, Roma people and other groups that are targets of hate). ${ }^{17}$ The latter seem to play an important role, not only in transmitting a message concerning the group's ideology, but also in emphasising the existence of a numerically significant organisation behind the website.

Video and music downloads characterised by political content are especially common in political movements, as well as in Nazi and nationalistic organisations not to mention, obviously, music groups. Moreover, among this content we find audio files of sermons and archival speeches (e.g. by leaders of fascist/Nazi regimes) ${ }^{18}$ or podcasts accompanying radical right-wing journals.

When it comes to subcultural youth radical-right websites, traditional hate symbols', related to the national-socialist past, are less present; instead, symbols borrowed from the left are used (on this point, see also Di Tullio 2006; not only the symbols of the Schwarze Front of the Strasser brothers are in use, but also some symbols copied such as Good Night Left Side, etc.). The fact that, in this context, the structure of the Internet - and above all its small levels of surveillance - renders it legally less dangerous to diffuse extremist or even forbidden views through the web is also noteworthy. This is particularly visible in the case of websites of groups connected to the Blood and Honour network and subcultural skinhead groups that are registered as political parties or associations, where the visual evidence collected from the websites could become evidence to be used in court in a delegalisation case. In addition, in the case of social media (in particular Facebook), 
the occurrence of hate symbols is less visible and explicit, due probably to the synchronic nature of the networks and a number of anti-fascist activists who monitor radical-right fan pages or profiles and report them to the site admins who often block the profiles in question and delete content. ${ }^{19}$

Unsurprisingly, hate symbols are particularly present on neo-Nazi and subcultural right-wing groups' websites (in $35.9 \%$ and $25.6 \%$ of cases respectively). These latter groups are also the most likely to have banners and seals with hate symbols (68.4\%). This is the case, for example, with a nationalist Czech site ${ }^{20}$ where, on entering one of the site's subpages, the viewer is presented with a picture including a slogan against the Islamisation of Europe and, in the background, there is a crescent symbol and a minaret and a woman in a niqab in front. On the website of Hungarian Arrabona Crew, there is a picture representing Israel as an oppressor in Palestine, calling for "Protest against Zionist world domination". Similarly, on the site of the Polish nationalistic organisation Zadruga we find a banner showing two men and a woman as 'the Germanic ideal' calling for 'fight, resistance and action' and a call directed at women to defend their blood and motherland, with a drawing of a naked woman wearing the group's armband, an ammunition belt, and military boots.

Finally, regarding the regional West vs. East comparison we can see (Table 13.2) that both visual and textual propaganda elements are, in general, as highly diffused among radical-right groups in the CEE region as among the Western European countries. However, hate symbols, bibliography, and news sections are more prevalent in the Western European radical-right websites. On the other hand, radicalright organisations in the CEE countries place banners more frequently on their webpages. According to these results, we can conclude that the radical-right groups both in Western and in Central and Eastern Europe use the same forms of online propaganda, since we did not find regional patterns in their online communication. Notwithstanding there are differences between the regions regarding the intensity/ frequency of some propaganda elements, suggesting that CEE countries are in the middle of the catching up process with the Western European radical right.

TABLE 13.2 Radical-right propaganda through the web in Western vs. Eastern Europe

\begin{tabular}{lll}
\hline & Central Eastern Europe & Western Europe* \\
\hline Hate symbols & $20.7 \%$ & $40.0 \%$ \\
Multimedia & $50.0 \%$ & $50.2 \%$ \\
Banner & $50.0 \%$ & $30 \%$ \\
Article & $66.0 \%$ & $62.4 \%$ \\
Bibliography & $17.6 \%$ & $37.3 \%$ \\
Slogan & $34.6 \%$ & $28 \%$ \\
Conference material & $7.4 \%$ & $11.8 \%$ \\
News section & $29.3 \%$ & $49.8 \%$ \\
\hline
\end{tabular}

*Data based on Caiani and Parenti (2013: 84-91). 


\section{Conclusion}

In this chapter, building on similar studies focussed on radical-right groups in Western Europe (Caiani and Parenti 2013), we have investigated the degree and forms of right-wing online propaganda in Central and Eastern Europe, a topic far from being developed in (social movement, media and communication) research.

By focussing on different kinds of radical-right organisations and conducting a formalised content analysis of the websites of almost 200 organisations based in four countries, our study showed radical-right CEE groups deploy a rich repertoire of action and variegated forms of political activism. The organisations under scrutiny emerged as fully aware of the new potentialities offered by the web; moreover, they appear able to effectively use these tools for their propaganda and mobilisation. Radical-right groups in the CEE region are practising online propaganda as actively as the Western European radical-right organisations.

First, radical-right organisations in our selected CEE countries use the Internet to reach their followers, to propagate their ideology and mission, and to build and re-affirm radical-right identity. Secondly, our study has also highlighted that Czech and Slovak radical-right organisations use visual and textual propaganda more actively than Hungarian and Polish ones. However, we found country differences in the usage of some particular elements of propaganda. Banners, hate symbols, and articles seem to be less frequent in Slovakia and the Czech Republic than in Hungary and Poland. Beyond country differences, our study also emphasised patterns of Internet political use related to the type of group at stake: focussing on the group differences we found that less 'institutionalised' groups (such as political movements and neo-Nazi organisations) use more visual propaganda elements with respect to more institutionalised groups, such as parties. Nevertheless, political parties are also actively using textual and visual propaganda on their webpages.

From a normative perspective, we must notice that through the Internet, people can access limitless news and information options. Where radical-right propaganda (e.g. anti-minority, pro-nationalism, advocating law and order, 'culture of obedience', etc.) and fake news emerge as a significant political force, the relationship between democracy and the Internet may become critical. Various 'watchdog' think tanks in Central and Eastern Europe (Globsec Report 2019) analysed fake news propaganda before the 2019 elections for the European Parliament in various CEE countries and found that the online media which spreads fake news content often used radical-right rhetoric, e.g. 'migration as a threat for the Christian Europe', Euroscepticism, 'nationalism as the only solution'. Moreover, these sources also often supported by radical-right parties, like Kotleba-L'SNS in Slovakia, SPD in the Czech Republic, or the ruling party Fidesz in Hungary. As also our study has shown, hate speech and radical-right (fake) news can be helped in their diffusion within society by the increasing Internet use of radical-right organisations (Klein 2019). This, although still rarely investigated - especially in the East - can work as an additional factor explaining the electoral success of the institutional radical right (Greskovits 2020). 


\section{Notes}

1 In the media and social sciences, actors on the political right of the spectrum are referred to by multiple interrelated concepts, with the term 'extreme right' often used interchangeably with labels like 'fascist', 'Nazi', 'rightist', 'right-wing', '(ultra)conservative', '(ultra)nationalist', 'populist right', and 'radical right', as well as 'extreme right' (Carter 2017).

2 In addition, national identity is shaped by the political and economic transformation process in the late 80 s, and early 90 s, which in the CEE countries has been regarded as 'modernisation'. This is significantly different than Western European societies' change from industrialism to post-industrialism (Minkenberg 2017, ch 2.).

3 The web content analysis was conducted between January and March 2017 by coders (proficient in the language of the specific country) trained in the sampling selection and coding procedure.

4 For a similar method and tool of analysis, see Caiani and Parenti 2013, but also more generally: Gerstenfeld, Grant, and Chiang 2003; Zhou et al. 2005; Qin et al. 2007.

5 In this class we inserted those groups defining themselves as political parties. In the case of these radical right parties, scale of importance and popularity is very wide. There are small and marginal parties containing just a few members and activists, other parties are active at the local level only. However, there are nationwide vivid parties that openly partake in elections, and sometimes enter the national assembly (especially in Slovakia and Hungary) (see Minkenberg 2017: 69-72 for a detailed list on radical right-wing parties in the CEE region).

6 Political movements are less institutionalised actors that do not run for public offices, but rather "try to mobilize public support" (Minkenberg 2017: 25). This category includes "party parallel organizations" (Veugelers and Menard 2018), referring to associations relating to political parties (for example, 64 county youth movement Hatvannégy vármegye ifjúsági mozgalom in Hungary, and Endecja Club, a movement of young intellectuals in Poland). In the category 'political movements', we have included also political journals and magazines that are often close to political parties (for example, Délnické listy in the Czech Republic, and the monthly magazine Právo národa in Slovakia).

7 Neo-Nazi organisations refer to the German Nazis or their ideological cousins in the four examined countries (as the Hungarist movement in Hungary) (Mareš and Stojar 2012). Their sites often contain Nazi and neo-Nazi symbols (for example, the arrow cross) and references to events and nationalist leaders of the interwar period (Blood and Honour, Jozef Tiso, Ferenc Szálasi). Neo-Nazi groups also talk about purity of the Aryan race, white power, and racial hatred (for example, prisoners of war in the Czech Republic).

8 The nostalgic, revisionist, and negationist sites provide document collections on history (mostly on World War II). Revisionists often deny Nazi crimes, and bring vague, distorted interpretations of history. The main themes are the rewriting of history and documentation of the communists' crimes. According to Tucker "revisionist attempts to confuse knowledge with fiction, and founded on bad philosophy, invalid arguments and misunderstandings of contemporary epistemology and philosophy of science" (Tucker, 2008: 3, cited by Petó 2017). In the Hungarian context, there are a bunch of organisations referring to the Horthy Era, which spanned between the two World Wars. The main characteristics of these groups are the condemnation of the Trianon Treaty, and nostalgic feeling for Greater Hungary.

9 As Veugelers and Menard (2018) highlight, publishers play an important role in the radical-right's non-party sector. There are publishers and online shops who sell classical Nazi-fascist texts, memoirs, and also gadgets. The radical right has its own lifestyle which is characterised by specific clothing, clothing brands (Miller-Idriss 2017), and music styles. (Pollard 2016) That category is characterised by the commercial nature of the sites.

10 Subcultural organisations contains 'small groups' such as football fan clubs, skinhead music bands, (Veugelers and Menard 2018) or graffiti and hooligan groups. Some ER groups in Western Europe use the symbols of Celtic mythology or look at a sort of new 
spiritualism challenging the official Christian religion. Pollard (2016) calls it Odinims, referring to the ancient German god. In the Central-East European region, there has also been a "tendency to appropriate elements of pre-Christian religious mythologies, including ancient Slavonic religions" (Pollard 2016: 410) In Hungary, pagan mythology and symbols are current in all social strata. This subcultural milieu is dominated by cultural elements of the early Hungarian history, like archery, horse riding, runic alphabet, traditional clothes.

11 Right-wing nationalist groups are close to the category of what Veugelers and Menard (2018) call political sects. "For sects, be they religious or political, the number of members matters less than their worthiness." (p.420) These groups highlight that morality is the most important (for example, the Czech Pro-Vlast). This category includes military groupuscules as well as the Polish Defence League.

12 In our analysis, we have distinguished between propaganda directed towards insiders, namely members and/or sympathisers, and propaganda directed toward a larger public (outsiders).

13 See, for example, the website for Droga Legionisty, http://drogalegionisty.pl/.

14 We relied here on the FIFA and UEFA catalogue of hate symbols, usually banned from stadiums and football games.

15 After rising popularity of radical right in Slovakia, restrictive legal measures have been introduced. (see Strážnická 2017).

16 Banners are images (GIF, flash) usually in a high-aspect ratio shape, often employing animation, sound, or video.

17 For example, see the website of the Slovak neo-Nazi group: https://vzdoruj.wordpress. $\mathrm{com} /$.

18 For example, on https://aryanrebel.wordpress.com/.

19 Such anti-fascist and watch dog organisations are: in Czech Republic, e.g. Liga lidských práv or Nadace Tolerance. In Hungary, e.g. Tett és Védelem Alapítvány or TASZ. In Slovakia, e.g. European Roma Grassroots Organisations Network or Amnesty International, Human Rights Watch. In Poland e.g. HejtStop organisation focussing on hate speech, and the group Otwarta Rzeczpospolita working against discrimination.

20 www.nationalisti.wordpress.com.

\section{References}

Andreescu, G. (2015) 'The emergence of a new radical right power', in: M. Minkenberg (ed.), Transforming the Transformation?: The East European Radical Right in the Political Process, London - New York: Routledge, 251-77.

Arzheimer, K. (2015) 'The AfD: Finally a successful right-wing populist Eurosceptic party for Germany?', West European Politics 38(3): 535-56.

Bartlett, J., J. Birdwell, M. Littler (2011) The New Face of Digital Populism, New York: Demos.

Bennett, W.L., C. Breunig, T. Givens (2008) 'Communication and political mobilization: Digital media and the organization of anti-Iraq war demonstrations in the US', Political communication 25(3): 269-89.

Bennett, W.L., A. Segerberg (2013) The Logic of Connective Action: Digital Media and the Personalization of Contentious Politics, Cambridge: Cambridge University Press.

Bernhard, L., H. Kriesi, (2019) 'Populism in election times: A comparative analysis of 11 countries in Western Europe', West European Politics 42(6): 1188-208.

Berntzen, L. E., M. Weisskircher (2016) 'Anti-Islamic PEGIDA beyond Germany: Explaining differences in mobilisation', Joumal of Intercultural Studies 37(6): 556-73.

Buštíková, L. (2018) 'The radical right in Eastern Europe', in: J. Rydgren (ed.), The Oxford Handbook of the Far Right, Oxford: Oxford University Press. 
Caiani, M. (2019) 'Radical right wing movements: The rise and endurance', Current Sociology 1-18, doi: 10. 1177/00 11392119868000 (early view).

Caiani, M., O. Císař, (eds) (2018) Radical right movement parties in Europe, London - New York: Routledge.

Caiani, M., D. Della Porta, C. Wagemann (eds) (2012) Mobilizing on the Far Right: Germany, Italy, and the United States, Oxford: Oxford University Press.

Caiani, M., P. Kroel, (2014) 'A transnational extreme right? New right-wing tactics and the use of the Internet', Intemational Joumal of Comparative and Applied Criminal Justice 39(3): 1-21.

Caiani, M., L. Parenti (2013) The Dark Side of the Web: European and American Right-Wing Extremist Groups and the Intemet, London: Ashgate

Carter, E. (2017) 'Party ideology', in: C. Mudde (ed.), The Populist Radical Right. A Reader, New York: Routledge, 28-67.

Casas, A., N. Webb Williams (2017) 'Images that matter: Online protests and the mobilizing role of pictures', Political Research Quarterly 72(2): 360-75.

Castelli Gattinara, P., A. L. Pirro (2019) 'The far right as social movement', European Societies $21(4): 447-62$.

Císař, O. (2017) 'Social movements after communism', in: A. Fagan, P. Kopecký (eds), The Routledge Handbook of East European Politics, London: Routledge, 184-96.

Císař, O., V. Štětka (2016) 'Czech Republic: The rise of populism from the fringes to the mainstream', in: T. Aalberg, F. Esser, C. Reinemann, J. Stromback, C. De Vreese (eds), Populist Political Communication in Europe, New York: Routledge, 285-98.

De Koster, W., D. Houtman (2008) 'Stormfront is like a second home to me. On virtual community formation by right-wing extremists', Information, Communication $G$ Society 11(8): 1155-76.

Della Porta, D., L. Mosca (2006) 'Democrazia in rete: stili di comunicazione e movimenti sociali in Europa', Rassegna Italiana di Sociologia 47(4): 529-56.

Di Tullio, D. (2006) Centri sociali di destra: occupazioni e culture non conformi, Rome: Castelvecchi.

Dolata, U., J.F. Schrape (2016) 'Masses, crowds, communities, movements: Collective action in the internet age', Social Movement Studies 15(1): 1-18.

Ekman, M. (2018) 'Anti-refugee mobilization in social media: The case of Soldiers of Odin', Social Media+ Society 4(1): 1-11.

Enikolopov, R., A. Makarin, M. Petrova (2016) Social Media and Protest Participation: Evidence from Russia (No. 11254), CEPR Discussion Papers.

Europol (2019) 'Internet facilitated organized crime threat assessment' (IOCTA).

Fofiu, A. (2015) 'Stories of a white apocalypse on the Romanian Internet', in: V. Watson, D. Howard-Wagner, L. Spanierman (eds), Unveiling Whiteness in the Twenty-First Century: Global Manifestations, Transdisciplinary Interventions, Lanham - Boulder - New York London: Lexington Books, 29-47.

Gerstenfeld, P.B., D.R. Grant, C. Chiang (2003) 'Hate online: A content analysis of extremist Internet sites', Analysis of Social Issues and Public Policy 3(1): 29-44.

Globsec Report (2019) 'European elections in Central Europe: Information operations and disinformation campaigns', www.globsec.org/wp-content/uploads/2019/05/EP-Elec tions_Information-Operations-Disinformation-Campaigns-1.pdf.

Greskovits, B. (2020) 'Rebuilding the Hungarian right through conquering civil society: the Civic Circles Movement', East European Politics 36(2): 247-66.

Hutter, S. (2014) Protesting Culture and Economics in Westem Europe: New Cleavages in Left and Right Politics, Minneapolis: University of Minnesota Press.

Karl, P. (2017) 'Hungary's radical right 2.0', Nationalities Papers 45(3): 345-55. 
Kharroub, T., O. Bas (2016) 'Social media and protests: An examination of Twitter images of the 2011 Egyptian revolution', New Media \& Society 18(9): 1973-92.

Klein, O. (2019) 'Misleading memes. The effects of deceptive visuals of the British National Party', paper peresented at the annual SISP conference, University of Lecce 11-14 Sept. 2019.

Klein, O., J. Muis (2019) 'Online discontent: Comparing Western European far-right groups on Facebook', European Societies 21(4): 540-62.

Kluknavská, A., M. Hruška (2019) "We talk about the "others" and you listen closely: The extreme right communication on social media', Problems of Post-Communism 66(1): $59-70$.

Krämer, B. (2017) 'Populist online practices: The function of the Internet in right-wing populism', Information, Communication \& Society 20(9): 1293-309.

Krekó, P., A. Juhász, Cs. Molnár (2011) 'A szélsôjobboldal iránti társadalmi kereslet növekedése Magyarországon', Politikatudományi Szemle 20(2): 53-79.

Kriesi, H. (2014) 'The populist challenge', West European Politics 37(2): 361-78.

Kriesi, H. (2018) 'Revisiting the populist challenge', Politologický casopis-Czech Joumal of Political Science 25(1): 5-27.

Kriesi, H., E. Grande, R. Lachat, M. Dolezal, S. Bornschier, T. Frey (2008) West European Politics in the Age of Globalization, Cambridge: Cambridge University Press.

Kriesi, H., T.S. Pappas (eds) (2015) European Populism in the Shadow of the Great Recession, Colchester: ECPR Press, 1-22.

Mareš, M., R. Stojar, (2012) 'Extreme-right paramilitary units in Eastern Europe', in: A. Mammone, E. Godin, B. Jenkins (eds), Mapping the Extreme Right in Contemporary Europe: From Local to Transnational, Abingdon: Routledge, 159-72.

Miller-Idriss, C. (2017) 'Soldier, sailor, rebel, rule-breaker: Masculinity and the body in the German far right' Gender and Education 29(2): 199-215.

Minkenberg, M. (2013) 'From pariah to policy-maker? The radical right in Europe, West and East: Between margin and mainstream', Joumal of Contemporary European Studies 21(1): 5-24.

Minkenberg, M. (2015) Transforming the Transformation?: The East European Radical Right in the Political Process, Abingdon: Routledge.

Minkenberg, M. (2017) The Radical Right in Eastern Europe: Democracy Under Siege?, Berlin: Springer.

Monti, M. (2018) 'The new populism and fake news on the internet: How populism along with Internet new media is transforming the fourth estate', Stals Research paper 4.

Mudde, C. (ed.) (2007) Populist Radical Right Parties in Europe, Belgium: University of Antwerp.

Mudde, C. (2017). 'Politics at the fringes? Eastern Europe's populists, racists, and extremists', in: A. Fagan, P. Kopecký (eds), The Routledge Handbook of East European Politics, London: Routledge, 254-64.

Mudde, C. (2019) The Far Right Today, Cambridge: Polity.

Petô, A. (2017) 'Revisionist histories, "future memories": Far-right memorialization practices in Hungary', European Politics and Society 18(1): 41-51.

Pirro, A.L.P. (2015a), The Populist Far Right in Central and Eastern Europe: Ideology, Impact, and Electoral Performance, London: Routledge.

Pirro, A. L.P. (2015b) 'The populist far right in the political process - Assessing party impact in Central and Eastern Europe', in: M. Minkenberg (ed.), Transforming the Transformation?: The East European Far Right in the Political Process, London: Routledge, 80-104.

Pollard, J. (2016) 'Skinhead culture: The ideologies, mythologies, religions and conspiracy theories of racist skinheads', Patterns of Prejudice, 50(4-5): 398-419. 
Powell, T.E., H. G. Boomgaarden, K. De Swert, C. H. de Vreese (2015) 'A clearer picture: The contribution of visuals and text to framing effects', Joumal of Communication 65(6): 997-1017.

Pytlas, B. (2013) 'Radical-right narratives in Slovakia and Hungary: Historical legacies, mythic overlaying and contemporary politics', Patterns of Prejudice 47(2): 162-83.

Pytlas, B. (2015) Radical Right Parties in Central and Eastem Europe: Mainstream Party Competition and Electoral Fortune, London: Routledge.

Qin, J., Y. Zhou, E. Reid, G. Lai, H. Chen (2007) 'Analyzing terror campaigns on the internet: Technical sophistication, content richness, and web interactivity', International Joumal of Human-Computer Studies 65(1): 71-84.

Rydgren, J. (2007) 'The sociology of the radical right', Anmual Review of Sociology 33: 241-62.

Strážnická, A. (2017) 'Extremism in Slovakia - throughout analysis', European Journal of Transformation Studies 5(2): 60-68.

Street, J. (2011) Mass Media, Politics and Democracy, Basingstoke: Palgrave Macmillan.

Tucker, A. (2008) 'Historiographic revision and revisionism', in: M. Kopecek (ed.), Past in the Making. Historical Revisionism in Central Europe, Budapest: CEU Press, 1-15.

Van Laer, J., P. Van Aelst (2010) 'Internet and social movement action repertoires: Opportunities and limitations', Information, Communication \& Society 13(8): 1146-71.

Veugelers, J., G. Menard (2018) 'The non-party sector of the radical right', in: J. Rydgren (ed.), The Oxford Handbook of the Radical Right, Oxford: Oxford University Press, 285-304.

Zhou, Y., E. Reid, J. Qin, H. Chen, G. Lai (2005) 'U.S. domestic extremist groups on the web: Link and content analysis', IEEE Intelligent Systems 20(5): 44-51. 